\title{
The Moderating Effect of Institutional Ownership on Intellectual Capital and Financial Performance of Listed Conglomerates
}

\author{
Isah Umar Kibiya ${ }^{*}$, Bilyaminu Shittu Aminu ${ }^{2}$, Khadija Salihu Abubakar ${ }^{3}$ \\ 1,3 Department of Accounting, Al-Qalam University Katsina. Katsina- Nigeria \\ 2 Jigawa State Polytechnic, Dutse, Jigawa State- Nigeria \\ * Corresponding author: isahkibia@gmail.com
}

Article History

Received 2019-04-25

Accepted 2019-07-16

Published 2019-08-10

\section{Keywords}

Intellectual capital

Institutional ownership

Return on Assets

How to cite?

Kibiya, I. U., Aminu, B. S., \&

Abubakar, K. S. The Moderating Effect of

Institutional Ownership on Intellectual

Capital and Financial Performance of

Listed Conglomerates. SEISENSE

Journal of Management, 2(5), 20-28.

doi:10.33215/sjom.v2i5.151
Abstract

Purpose- The study aims to examine the moderating effect of institution on the relationship between intellectual capital on the financial performance of conglomerates in Nigeria

Design/Methodology- correlational research design which is based on historical data extracted from annual report and accounts of the sample firm on NSE. Firms were chosen based on censor sampling method. Eleven years of financial data were used. Multiple regression analysis was employed to analyze the data extracted.

Findings- The results from pooled ordinary least square regression (OLS) and Fixed effect revealed that intellectual capital indexed by a value-added intellectual coefficient (VAIC) has a positive and significant impact on financial performance indexed by return on asset (ROA) of listed conglomerate firms in Nigeria. Furthermore, the interaction effect of institutional ownership was found to be positive and significant

Practical Implications- The study recommends that institutional shareholders should invest more in shares of listed conglomerate firms in Nigeria and that management should recognize the effort and understand the importance of intellectual capital toward improving firm performance. 


\section{Introduction}

In today's global competitive market, intellectual capital (IC) has become one of the essential components of business and strategic resources with more sustainable to remain relevant in a competitive environment (Hayati, Yurniwati, \& Putra, 2015). IC is the intangible value of a business, that is the value of an organization's employee knowledge, skills, training, and staff development as well as information that may provide Company with a competitive advantage. Its seen as one of the intangible non-current assets, the disclosure of its information provide the internal and external users with relevant information that may use to drive profits, create and maintain customers and also improve the general performance of a business. IC is a material which has been formalized and used to produce higher value for the business ((Hayati et al., 2015). (Bontis, 1998) and (Choudhury, 2010) defined IC as total knowledge that is surrounded in the personnel, organizational routines and network relationships of an organization. Intellectual capital is the efforts of an organizational employee put into an entity in the form of intangible assets that determine the value of its competitiveness (Uzoma \& Rita, 2017). Intellectual capital contained three major components, human capital, structural capital, and capital employed. Human capital is defined as the possession of skills, knowledge, and experience by the organizational employee's concerning their value or cost to an organization. Structural capital is the supportive infrastructure that enables the rest of an organization to function in a repeatable scalable way. (Uzoma \& Rita, 2017) described structural capital as the company's culture which consists of values, beliefs, and norms of behavior that are shared and accepted y firm's employee's. its owned by the company and it remains with the company in the event an employee left the organizations. Customers capital employed is the last component of intellectual capital, represents the potential that the firm has for intangible items outsides of the firms.

The corporate performance was previously linked to its income and expenses level of the business, but today this assertion loses its absolute meaning and impact, as it has been supposed that organization's performance was due to proper management of intellectual capital (Karami, Moradi, \& Rezaie, 2015). Moreover, it has been established in the extant literature that intellectual capital plays a key role in determining firm performance (Chidiebere \& $\mathrm{Ph}, 2013$ ). This is due to the fact intellectual capital coordinate other physical assets of the organization. Companies investment in intellectual assets is considered an important determinant of a firm's competitive advantage (Noradiva, Parastou, \& Azlina, 2015). Uzoma and Rita (2017) posit that intellectual capital contributed to firm performance, therefore, it's of paramount importance and should receive reasonable attention from the company's management.

The management of a firm's intellectual assets and other physical is responsible for managers who are equally responsible for taking strategic decision. therefore, Effective and efficient utilization of intellectual capital will positively affect firm performance. Consequently, managers are anticipated to have significant influence towards the firm's investment and management of intellectual capital, this suggests that managers need to be monitor to ensure proper utilization of intellectual assets. Therefore, this study intends to examine the role of institutional ownership on the relationship between intellectual capital and the firm's financial performance of listed conglomerate firms in Nigeria.

\section{Literature Review}

Intellectual capital stands as knowledge resources that the organization used to attain its goals. Therefore, the success or otherwise of the organization depends on creating, discovering, capturing, disseminating and measuring knowledge. In other words, if organizations increase the productivity of their organizational learning. Hence, learning is an ongoing, never-ending and always changing process base on the changing of the market. It is the foundation of adaptability and innovation and in the last two and half decades, the 
importance of IC has been improved tremendously specifically in developing and developed companies (Salman \& Dandago, 2013)

The resource-based theory is one of the theories used to understand the influence of intellectual capital on firm performance (Purwaningsih, 2018). it's seen the resource as key to superior firm performance. The resource-based theory is given a crucial role in helping companies in achieving higher organizational performance. The intangible resources which have been developed internally have the potential to be the more profit's creators compared to resources which are acquired (Ermawati, Noch, Ikhsan, \& Khaddafi, 2017). Therefore, the resource-based theory was used to underpin this study.

Prior studies that examine the empirical relationship between intellectual capital and financial performance includes Chidiebere and $\mathrm{Ph}$ ( 2013) examines the relationship between intellectual capital and growth in revenue of six deposit money banks in Nigeria from 2000- 2011. The multiple regression results reveal a positive and significant impact of intellectual capital component (VAIC) on revenue growth of deposit money banks. The sample size of six banks without justification was not an adequate representation of deposits money banks in Nigeria. Al-matari, Hanim, Fadzil, and Al-swidi (2014) examined the interacting effect of board diversity on the relationship between the board of directors attributes and firm performance. The results from multiple regression revealed that the board of director's characteristics namely board size, board meeting, CEO tenure, board independence, and CEO duality do not affect firm performance represented by ROA. Also, the study found that the moderating was not significant on the board of director's characteristics and performance.

Nuryaman (2015) used profitability as intervening variables to examine the relationship between intellectual capital and the firm's value. The study was based on 93 sample firms listed on the Indonesian stock exchange for the single year of 2012. The study found a positive and significant effect of intellectual capital measures by VAIC on firm value, the study further reveals profitability represented by ROA serves as mediating variables. This suggests that intellectual capital improve the profitability of the sample companies which in turn results in the high market value of the samples firms.

Olayiwola (2016) studied the human capital accounting information and firm value of selected manufacturing firms in Nigeria for eight years (2007-2014). The empirical results from both Pooled ordinary least square and fixed-effect model indicates a positive and significant influence of human capital accounting information on the share price of manufacturing companies in Nigeria. The share price used as a measure of value is a times series data, the selection process was not disclosed by the scholar. Noradiva et al. (2015) examined the moderating effect of managerial ownership on the relationship between intellectual capital and firm value of 46 listed firms on the ACE Market of Bursa from 2009-2012. The results from multiple regression analysis show a positive and significant impact of intellectual on firm value. They also, found that managerial ownership does not moderate the relationship. Studies of this nature required more timeframe, therefore the period covered by the study is too short. Furthermore, other ownership diversity such as institutional ownership and ownership concentration could moderate the relationship. In the same vein, Onyekwelu, Uche, Okoh, Johnson, and Iyidiobi (2017) studied the effect of intellectual capital on the financial performance of banks in Nigeria. Data for the study were extracted from the sample banks for ten years from 2004-2013. The study revealed that intellectual capital has a positive and significant impact on financial performance. The study failed to state its population and sample size, similarly, the study is aged.

Similarly, Shafi'u, Noraza, and Saleh (2018) examines the effect of intellectual capital on the financial performance of listed foods products companies from 2010 - 2014, they adopted the public model of IC known as Value added intellectual coefficient (VAIC). The results from multiple regression analysis show a positive and significant effect of VAIC on financial performance represented by ROA. This suggests that 
intellectual capital improve firm efficiency. On the other hand, Ozkan, Cakan, and Kayacan, (2017) investigated the effect of intellectual capital on the financial performance of the Turkish banking sector. Using component of value-added intellectual coefficient (HCE, SCE \& CE) between 2005- 2014, the study found no significant impact of VAIC on financial performance represented by return on assets. Different results could be obtained if a similar study is carried out in Nigeria due to the difference in the regulatory framework and institutional settings.

Ofurum and Aliyu, (2018) studied the impact of the intellectual component on the financial performance of listed banks in Nigeria. The results from the ordinary least square regression analysis revealed that Human capital has a positive and insignificant impact on revenue growth, whereas positive and significant to return on investment. They concluded that intellectual capital has not fully impacted the financial performance of listed deposit money banks in Nigeria. Also, Purwaningsih (2018) examined the moderating effect of ownership structure on the relationship between intellectual capital and financial performance of listed manufacturing firms in Malaysia. The results show that institutional ownership has a negative and significant impact on financial measured by ROA, while managerial ownership has a positive and significant impact on financial performance. Also, the study revealed that both ownership diversity does not strengthen the relationship between intellectual capital and financial performance.

Mohammad, Bujang, and Hakim, (2018) found that value-added intellectual capital has a positive and significant impact on financial performance. However, only capital employed efficiency (CEE) has a positive and significant impact on financial performance. This suggests that intellectual capital has not fully influenced the financial performance of listed construction firms in Malaysia. In the same vein, Nassar (2018) studied the impact of intellectual capital on firm performance of the 27 listed Turkish real estate companies before and after the crisis throughout 2004-2015. The results from the ordinary least square regression analysis show that SCE has a positive and significant impact on MB, ROE, and EPS before the crisis and with ROA and ROE after the crisis. On contrast, HCE shows a positive and significant impact on ROA and ROE before the crisis and negatively significant to MB and ATO after the crisis. Whereas CEE shows negative and significant on ATO after the crisis. Also, the results indicate that VAIC has a positive and significant impact on ROA, ROE, and EPS before the crisis, while it maintained the same positive impact on ROE after the crisis. This implies that intellectual capital has influenced the financial performance of listed real estate in Turkey.

\section{Methodology}

This study used the ex-post factor research design. The population of the study comprises the entire six firms listed under the conglomerates sub-sector of the Nigerian manufacturing sector, out of which five firms were used as sample size between 2007 - 2017, transnational Corp Nig. Itd were excluded due to incomplete data within the period of the study. Secondary data were extracted from the annual report and account of the sample firms. Panel data multiple regression analysis was used as techniques of data analysis. The choice of multiple regression is centered on its ability to predict empirical relationship. The model of study captures the moderating effect of institutional ownership on the relationship between intellectual capital and performance. The model that test the hypothesis of the study is presented as follows:

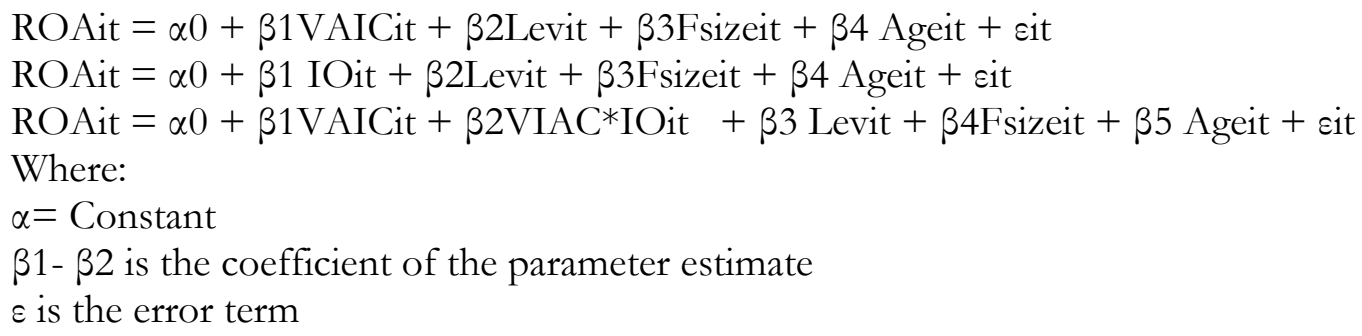


Table 1: Variable Definition and Their Measurement

\begin{tabular}{|c|c|c|c|}
\hline Variable & Definition & Measurement & Source \\
\hline Performance & ROA & Profit before tax scale total assets & (Saifullah, Mohammed, \& \\
\hline \multirow[t]{3}{*}{ VAIC } & $\mathrm{HC}+\mathrm{SC}+$ & HC $=$ Valued added/Human Capital & Usman, 2015) \\
\hline & $\mathrm{CE}$ & SC $=$ Structural Capital/Valued added & \\
\hline & & $\mathrm{CE}=$ Valued added $/$ Capital Employed & (Chidiebere \& Ph, 2013) \\
\hline $\begin{array}{l}\text { Institutional } \\
\text { ownership }\end{array}$ & $\mathrm{IO}$ & $\begin{array}{l}\% \text { of Shares held by institutions to the total } \\
\text { number of shares }\end{array}$ & (Garko, 2015) \\
\hline Leverage & Lev & $\begin{array}{l}\text { Interest-bearing debt scale by total assets } \\
\text { Natural log of total assets }\end{array}$ & (Sani, 2016) \\
\hline Firm Size & Fsize & Difference between the year of observation & (Garko, 2015) \\
\hline Firm age & age & and year of listing & (Sani, 2016) \\
\hline
\end{tabular}

Source: Generated by the researchers

\section{Results \& Discussion}

This section present analyzes and interprets the results of the data generated from the annual report of listed conglomerates companies in Nigeria.

Table 2: Descriptive Statistics of the Variables

\begin{tabular}{llllllll}
\hline Variables & Obs. & Mean & Std. Dev. & Min & Max & $\operatorname{Pr}($ Skewness) & $\operatorname{Pr}($ Kurtosis) \\
\hline ROA & 50 & 0.0238 & 0.1282 & -0.3183 & 0.3624 & 0.2885 & 0.0794 \\
VAIC & 50 & 40.5417 & 80.2225 & -1.0073 & 280.3488 & 0.0000 & 0.0269 \\
IO & 50 & 0.6108 & 0.1863 & 0.0000 & 0.9000 & 0.0022 & 0.0056 \\
Fsize & 50 & 10.0476 & 0.2524 & 9.4500 & 10.4946 & 0.3915 & 0.2850 \\
Lev & 50 & 0.2020 & 0.2429 & 0.0000 & 0.9975 & 0.0002 & 0.0573 \\
Age & 50 & 35.500 & 3.3579 & 29.000 & 42.000 & 0.9163 & 0.1432 \\
\hline
\end{tabular}

Source: Stata output

Table 2 shows the measurement of financial performance ROA has a mean value of 0.0238 with a standard deviation of 0.1282 , a minimum value of -0.3183 and maximum value of 0.3624 . This implies that on average earned a profit of $2.38 \%$ on assets and a maximum profit of $36.24 \%$ with a loss of $32 \%$ within the period of the study. The standard deviation of 0.1282 signified that the performance is diverse. Also, intellectual capital represented by a valued-added intellectual coefficient(VAIC) has an average value of 40.5417 with a maximum value of 280.3488 and a minimum value of -1.0073 . The standard deviation of 80.2225 signified a significant deviation in the composition of the value-added intellectual coefficient. Institutional ownership measure as the proportion of shares held by the institution has a mean of $61 \%$, with a minimum of $0 \%$ and a maximum of $90 \%$. The standard deviation of $18.6 \%$ indicates low dispersion among the sample companies.

Similarly, firm size measured as the logarithm of total assets has a mean value of 10.0476, with a minimum value of about 9.45 , and a maximum value of about 10.4946 . But the standard deviation of 0.2524 suggests moderate dispersion. Table 4.2 also shows that leverage has a mean score of $20 \%$, with a minimum of $0 \%$ and a maximum of $99 \%$. The standard deviation of 0.2429 signified insignificant dispersion among sample companies. Finally, the firm age has an average score of 35.5, with a minimum of about 29 and a maximum of about 42 . The standard deviation of 3.3539 suggests wider dispersion from the mean value. 
Table 3: Correlation Matrix of the Dependent and Explanatory Variables

\begin{tabular}{llllllll}
\hline Variables & ROA & VAIC & IO & Fsize & Lev & Age & VIF \\
\hline ROA & 1.0000 & & & & & & 1.31 \\
VIAC & 0.3130 & 1.000 & & & & 1.01 \\
IO & 0.1794 & 0.3126 & 1.0000 & & & 1.84 \\
Fsize & 0.5459 & 0.2809 & 0.2008 & 1.0000 & & 1.23 \\
Lev & -0.6571 & -0.1661 & -0.0419 & -0.3970 & 1.0000 & & 1.78 \\
Age & 0.0641 & 0.1353 & 0.1588 & 0.4918 & 0.1147 & 1.0000 & \\
\hline
\end{tabular}

Source: Stata output

Table 3 show correlation matrix between the dependent variable and the explanatory variable. It shows the extent to which the paired variable is associated with each other in the regression model. The results moderate positive association between VAIC and Fsize on return on assets (ROA), with a weak positive association between institutional ownership and firm age on ROA. Leverage has a negative association with ROA. More so, to check for collinearity problem, a robustness test of Variance inflation factor was carried out, the results of which show the absence of multicollinearity.

Table 4: Regression Result

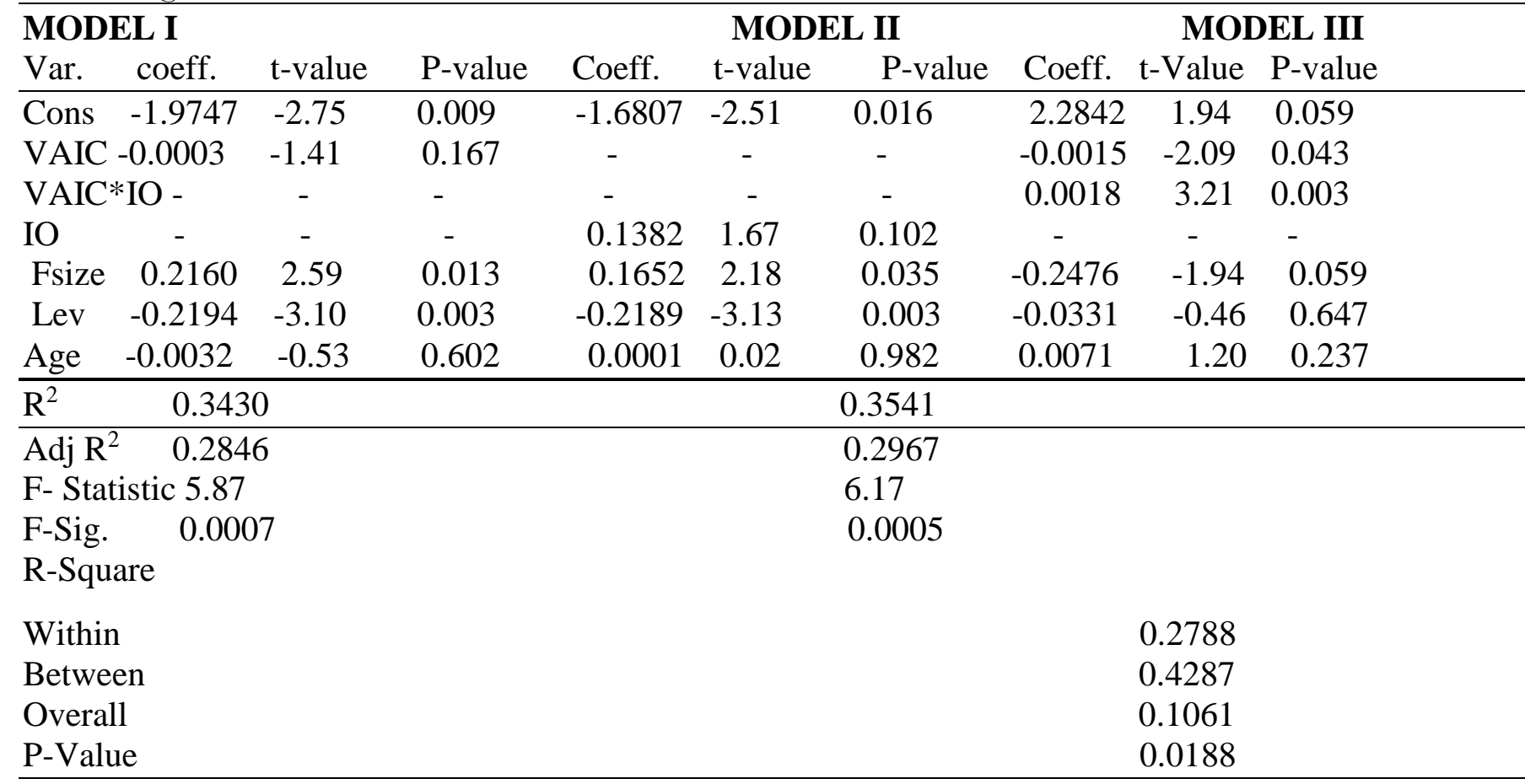

Table 4 present the regression results for the three model, the first model tests the impact of intellectual capital on the financial performance of listed conglomerates firms. The result reveals the negative and insignificant influence of intellectual capital on financial performance. This implies that intellectual capital does not influence financial performance. Whereas, model two predict the influence of moderating variable on the dependent variable. The R2and adjusted $\mathrm{R} 2$ shows $35 \%$ and $30 \%$ respectively which implies that a change in $\mathrm{ROA}$ is $30 \%$ caused by the variable selected in this study while the remaining $70 \%$ is caused by other variables not captures by this study. The F-statistics has a value of 6.17 with a P-value of 0.0005 , this indicates that the model is statistically fit to examine the impact of institutional ownership on financial performance. The regression results indicate that institutional ownership has no significant impact on financial performance. The last model which test the interaction effect of institutional ownership on the 
relationship between intellectual ownership on financial performance. Fixed effect model of Generalized least square regression (GLS) were presented. It was arrived after carrying out the Hausman specification test which favors fixed effect (P-Value 0.0008). The regression result shows that intellectual capital measures using VAIC have a negative and significant influence on financial performance, this is consistent with the findings of (Nuryaman, 2015) and (Shafi'u et al., 2018) but contrary to the findings of (Ozkan et al., 2017). furthermore, the interaction effect was found to be positive and significant on the relationship between intellectual capital and financial performance of listed conglomerate firms in Nigeria. The study concluded that institutional ownership having more experience than other equity diversity moderate positively to ensure efficient performance of conglomerate firms in Nigeria. Therefore, it's recommended that institutional shareholders should invest more in shares of listed conglomerate firms in Nigeria and that management should recognize the effort and understand the importance of intellectual capital toward improving firm performance.

Funding: This research received no external funding.

Acknowledgments: The authors acknowledged the contribution of Professor Muhammad Liman Muhammad and Professor Ibrahim Magaji Barde from Department of Accounting Bayero University KanoNigeria.

Conflicts of Interest: The authors declare no conflict of interest and no role play by outsiders.

\section{References}

Al-matari, E. M., Hanim, F., Fadzil, B., \& Al-swidi, A. K. (2014). The Moderating Effect of Board Diversity on the Relationship Between Board of Directors Characteristics and Firm Performance in Oman: Empirical Study Middle-East Journal of Scientific Research, 21(5), $782-791$. https://doi.org/10.5829/idosi.mejsr.2014.21.05.21605

Bontis, N. (1998). Intellectual capital: an exploratory study that develops measures and models. Management Decision, 36(2), 63-76. https://doi.org/10.1108/00251749810204142

Chidiebere, M., \& Ph, E. (2013). The Relationship between Intellectual Capitals and Growth in Revenue of Deposit Money Banks in Nigeria. 4(12), 55-65.

Choudhury, J. (2010). Performance Impact of Intellectual Capital: A Study of Indian it Sector. International Journal of Business and Management, 5(9), 72-80. https://doi.org/10.5539/ijbm.v5n9p72

Ermawati, Y., Noch, M. Y., Ikhsan, A., \& Khaddafi, M. (2017). Reconstruction of Financial Performance to Manage Gap between Value Added Intellectual Coefficient ( V AICTM ) and Value of Company in Banking Company Listed in Indonesia Stock Exchange. International of Economics and Financial Issues. 7(4), 537-549.

Garko, J. S. (2015). Corporate Governance Mechanisms and Voluntary Disclosure : Evidence From Listed Industrial Goods Companies in Nigeria.. Being a Thesis Submitted To the School of Post Graduate Studies, Bayero University Kano-Nigeria.

Hayati, M., Yurniwati, \& Putra, A. R. (2015). The Effect of Intellectual Capital to Value Relevance of Accounting Information Based on PSAK Convergence of IFRS (Manufacture Firms in Indonesia). Procedia - Social and Behavioral Sciences, 211(January), 999-1007. https://doi.org/10.1016/j.sbspro.2015.11.133 
Karami, P., Moradi, A., \& Rezaie, H. (2015). A comparative between the effect of physical capital and intellectual capital in improving university performance Introduction. International Journal of Business Management : 2(12), 54-63.

Mohammad, H., Bujang, I., \& Hakim, T. (2018). The Impact of Intellectual Capital on Financial Performance of Malaysian Construction Firms. International Journal of Academic Research in Business and Social Sciences, 8(5), 173-186. https://doi.org/10.6007/IJARBSS/v8-i5/4093

Nassar, S. (2018). The Impact of Intellectual Capital on Firm Performance of the Turkish Real Estate Companies Before and After the Crisis. European Scientific Journal, ESJ, 14(1), 29. https://doi.org/10.19044/esj.2018.v14n1p29

Noradiva, H., Parastou, A., \& Azlina, A. (2015). The Effects of Managerial Ownership on the Relationship between Intellectual Capital Performance and Firm Value. International Journal of Social Science and Humanity, 6(7), 514-518. https://doi.org/10.7763/ijssh.2016.v6.702

Nuryaman. (2015). The Influence of Intellectual Capital on The Firm's Value with The Financial Performance as Intervening Variable. Procedia - Social and Behavioral Sciences, 211(January), 292-298. https://doi.org/10.1016/j.sbspro.2015.11.037

Ofurum, C. O., \& Aliyu, A. S. (2018). Intellectual Capital Component and Financial Performance of Quoted Banks in Nigeria. International Journal of Advanced Academic Research and Financial Management $4(2), 24-46$.

Olayiwola, J. A. (2016). Human Capital Accounting Information and Firms' Value: An Analysis of Selected Quoted Manufacturing Companies in Nigeria (2007-2014). International Journal of Economics, Commerce and Management, IV(5), 14-27. Retrieved from http://ijecm.co.uk/

Onyekwelu, Uche, L., Okoh, Johnson, I., \& Iyidiobi. (2017). Effect of Intellectual Capital on Financial Performance of Banks in Nigeria. European Journal of Accounting, Auditing and Finance Research, 5(2), 28-57. Retrieved from www.eajournals.org

Ozkan, N., Cakan, S., \& Kayacan, M. (2017). Intellectual capital and financial performance: A study of the Turkish Banking Sector. Borsa Istanbul Review, 17(3), 190-198. https://doi.org/10.1016/j.bir.2016.03.001

Purwaningsih, E. (2018). The Influence of Value Added Intellectual Capital to Financial Performance with Ownership Structure as Moderating Variable. 8(3), 277-290. https://doi.org/10.6007/IJARAFMS/v8-i3/4836

Saifullah, M. A., Mohammed, A., \& Usman, S. H. (2015). Ownership Diversity and Corporate Performance: Evidence from Nigerian Conglomerates Firms. Journal of Basic and Applied Research, 1(1), 89-101.

Salman, R. T., \& Dandago, K. I. (2013). Intellectual Capital Disclosure in Financial Reports of Nigerian Companies. 1-17.

Sani, A. A. (2016). The Impact Of Ownership Structure and Cash Flow On Dividend Policy in the Nigerian Oil and Gas Industry. Being a Dissertation Submitted To the School of Post Graduate Studies, Bayero University Kano-Nigeria.

Shafi'u, A. K., Noraza, M. U., \& Saleh, M. B. (2018). The impact of intellectual capital on the financial performance of listed Nigerian food products companies. Journal of Accounting and Taxation, 9(11), 147-160. https://doi.org/10.5897/jat2017.0246 
Uzoma, C., \& Rita, N. (2017). Intellectual Capital Management and Organizational Performance in Selected Food and Beverage Companies in Nigeria. International Journal of Advanced Scientific Research and Management, 2(1), 47-58. 